\title{
The Effectiveness of Learning Sports through the Online Method on Kindergarten Students
}

\author{
Izzan Hanifan', Asri Wibawa Sakti',** \\ ${ }^{1}$ Departemen Pendidikan Kepelatihan Olahraga, Universitas Pendidikan Indonesia. \\ ${ }^{2}$ Departemen Pendidikan Kesejahteraan Keluarga, Universitas Pendidikan Indonesia. \\ *Corresponding author: achiewibawasakti@ upi.edu
}

\begin{abstract}
Abstrak:
Pembelajaran daring merupakan metode belajar dengan memanfaatkan teknologi yang memungkinkan terjadinya interaksi langsung. Kegiatan yang dilakukan untuk mengetahui efektivitas pembelajaran olahraga melalui metode daring dapat meningkatkan sehingga memudahkan tenaga pendidik dan orang tua murid. Termasuk pada pembelajaran Olahraga di Taman Kanak Kanak Harapan Bunda yang dilakukan secara daring. Metode pada penelitian ini menggunakan deskriptif kuantitatif dengan teknik pengumpulan data menggunakan kuesioner yang disebarkan melalui link Google Form. Hasil penelitian ini menunjukkan bahwa: (1) respon siswa: (a) keluhan secara psikis adalah: bosan 70\% dan tidak ada keluhan 30\% , (b) pemahaman materi pembelajaran olahraga: $50 \%$ mudah mengerti, 50\% tidak mengerti, (c) kebermanfaatan pembelajaran olahraga secara fisik: $70 \%$ merasakan dan $30 \%$ tidak merasakan, (d) Efektivitas pembelajaran: $40 \%$ mengatakan efektif dan 60\% mengatakan tidak efektif, (2) sarana dan prasarana: (a) jenis koneksi internet yang digunakan siswa: 70\% menggunakan kuota dan 30\% menggunakan WiFi, (b) kendala selama daring: $60 \%$ mengatakan kuota terbatas dan $40 \%$ mengatakan jaringan tidak stabil, (c) aplikasi yang mudah digunakan selama daring: 90\% mengatakan Whatsapp dan 10\% mengatakan zoom meeting, (3) aktivitas siswa: (a) sikap ketika guru menjelaskan materi: 100\% memperhatikan, (b) kesiapan mengikuti pembelajaran olahraga secara daring: $80 \%$ mengatakan siap dan 20\% mengatakan tidak siap, (c) kehadiran: 90\% hadir dan 10\% tidak hadir. Oleh karena itu, merujuk hasil penelitian dari indikator aktivitas siswa, sikap, kehadiran, dan kesiapan belajar menunjukkan hasil yang tinggi maka, efektivitas pembelajaran olahraga secara daring dapat ditingkatkan melalui sarana prasarana serta penggunaan aplikasi yang mudah digunakan saat proses pembelajaran.
\end{abstract}

Kata kunci: Daring, Efektivitas, Pembelajaran Olahraga, Taman Kanak-kanak

\begin{abstract}
:
Online learning is a learning method by utilizing technology that allows direct interaction. With this activity, it is hoped that the effectiveness of learning sports through online methods can improve making it easier for educators and parents. Including sports learning at Harapan Bunda Kindergarten which is carried out online. The method in this study uses quantitative descriptive data collection techniques using questionnaires distributed via Google Form links. The results of this study indicate that: (1) student responses: (a) psychological complaints are: $70 \%$ bored and no complaints 30\%, (b) understanding of sports learning materials: $50 \%$ easy to understand, $50 \%$ do not understand, $(c)$ the benefits of physical exercise learning: $70 \%$ felt and 30\% did not feel, (d) Learning effectiveness: $40 \%$ said it was effective and $60 \%$ said it was not effective, (2) facilities and infrastructure: (a) the type of internet connection used by students: $70 \%$ use quota and $30 \%$ use WiFi, (b) problems while online: $60 \%$ say limited quota and $40 \%$ say network is unstable, (c) applications that are easy to use while online: $90 \%$ say whatsapp and 10\% say zoom meeting, (3) student activities: (a) attitude when the teacher
\end{abstract}


explains the material: $100 \%$ pays attention, $(b)$ readiness to take part in online sports learning: $80 \%$ says ready and $20 \%$ says not ready, (c) attendance: $90 \%$ attends and $10 \%$ absent. Therefore, referring to engagement results from indicators of student activity, attitude, attendance, and readiness to learn shows high results, the effectiveness of online sports learning can be increased through infrastructure and the use of applications that are easy to use during the learning process.

Keywords: Effectiveness, Kindergarten, Online, Sport Learning

\section{Introduction}

Since the World Health Organization (WHO) informed about the existence of the Covid19 virus as a pandemic, the whole world has tried to stop and overcome the virus. This makes teachers have to think hard so that the teaching and learning process continues to be carried out effectively. Effective learning is a structured combination that includes human, material, facilities, equipment and procedures directed at changing student behavior in a positive and better direction in accordance with the potential and differences possessed by students to achieve the learning objectives that have been set. Sports learning is a lesson with many physical activities such as running, hitting, throwing, and jumping. After the Covid-19 virus, the teaching and learning process in Kindergarten moved to learning through online methods, this of course requires adequate facilities and infrastructure.

Kindergarten is a preschool educational institution that intends to foster child growth and development in the physical and spiritual fields, this education is given to children aged 4 to 6 years (Lola, 2020). In accordance with the results of previous activity, the implementation of online learning mostly uses the WhatsApp application, Zoom meeting, google form, and other applications that can be used for the implementation of learning (Handriani \& Oktafia Ika, 2020). Online learning through the WhatsApp application is less effective (Daheri, 2020). Judging from the readiness of kindergarten teachers to face online learning, it can be said that there are still teachers who are not ready to do online learning, although many also say they are ready (Trisnadewi, 2021). If the existing facilities are inadequate between the two parties, both teachers and parents become obstacles in the online learning (Ayuni, 2020). The implementation of online learning does need awareness from all parties so that this learning can be carried out properly (Wijoyo, 2020).

Based on the description above, we are interested in conducting activity with the title: The Effectiveness of Sports Learning Through Online Methods in Harapan Bunda Kindergarten Students. This activity is a quantitative descriptive study with data collection 
techniques using questionnaires which are then analyzed to determine the general description of the effectiveness of learning sports through online methods.

In a learning process, there are interrelated components so that the learning process can run well (Trisnadewi, 2021). These components consist of teachers, students, curriculum, context, methods and facilities (Arikunto, 2001). Learning is a process that runs effectively. Effectiveness in learning is a measure of the success of the interaction process in educational situations to achieve learning objectives (Islami et al., 2021).

Sports learning also has a goal to develop aspects of health, physical fitness, critical thinking skills and emotional stability which are presented as activities in the educational process. In the sports learning process, it is expected that teachers will be able to understand and apply learning systematics in order to achieve optimal learning outcomes. Providing understanding and knowledge to students can increase learning motivation, especially sports and reduce psychological problems by increasing immunity through learning sports at school (Marheni et al., 2020).

Interesting methods in the learning process can be a bridge to achieve the desired competencies (Maesaroh, 2013). Online is a new method of presenting information and facts that uses the help or intermediary of internet technology and has a very large contribution to the learning process (Hasanah \& Adi, 2021). Various media can support online learning methods including WhatsApp, and Zoom Meeting. Online learning can even be done through other social media platforms such as Facebook and Instagram (Firman \& Rahayu, 2020).

Learning in Kindergarten emphasizes children's self-development rather than reading, writing and arithmetic. As for those who say that the learning process in Kindergarten is different from the pattern of learning in schools in general, the right pattern is needed to train and develop physically and spiritually a child (Lola \& James Anderson, 2020). In addition, the pandemic has given new challenges in the learning process which was originally face-to-face to online, for theoretical learning, of course, there are no significant problems, but for practical sports learning to improve student fitness, physical activity is required in the teaching process. It should be noted that the learning process at the Kindergarten education level must continue, even more attention must be given to normal conditions because children need education to optimize all aspects of their development for the future in taking the next level (Islami et al., 2021). 
Jurnal Abdimas Kartika Wijayakusuma ISSN 2716-3512 (Online) ISSN 2721-0367 (Print)
This work is licensed under a Creative Commons Attribution-ShareAlike 4.0 International License.

CC BY SA

\section{Methods}

This study uses a quantitative descriptive approach with data collection techniques using questionnaires in the form of questions contained in Google Forms then distributed via WhatsApp Group Parents of Harapan Bunda Kindergarten Students, Indonesia. The number of respondents is 15 people. The type of questionnaire used is a closed questionnaire, namely the activity subject only chooses the answers that have been provided for each question. The framework in this activity is shown in Figure 1.

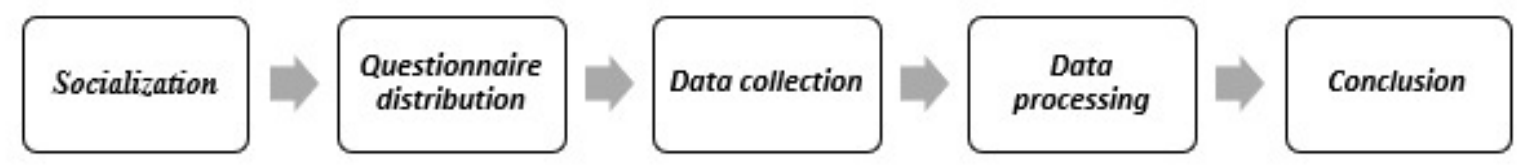

Figure 1. Method Framework

\section{Results and Discussion}

The results of sports learning counseling activities through online methods using Zoom Meeting with school principals and teachers of Harapan Bunda Kindergarten is shown in Figure 2. Meanwhile, counseling on sports learning and distributing questionnaires through online methods using the Whatsapp application to parents of Harapan Bunda Kindergarten students is given in Figure 3.

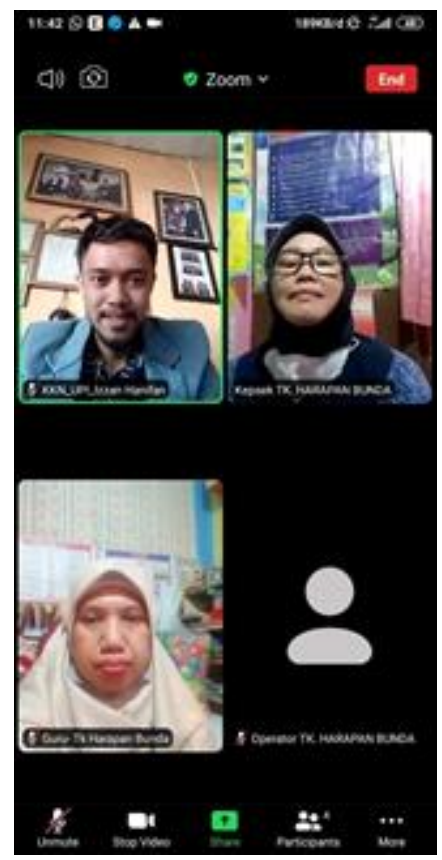

Figure 2. Kindergarten online learning socialization 


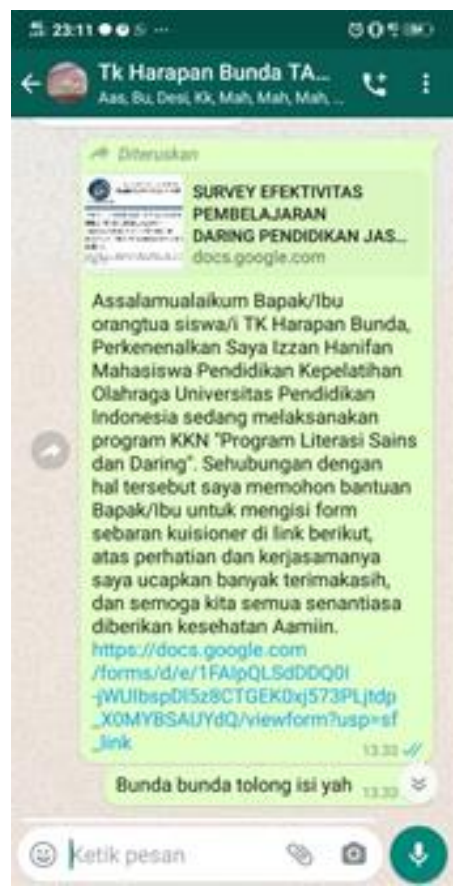

Figure 3. Distribution of questionnaires via Whatsapp

\subsection{Demographics}

The data for this study were obtained from questionnaires distributed online to respondents via the Google Form link. There are 10 questions arranged in the questionnaire covering 3 (three) kinds of indicators, namely 4 (four) questions about student responses, 3 (three) questions about facilities and infrastructure, and 3 (three) questions about student activities. After all respondents filled out the questionnaire, the data were analyzed, described and presented in the form of a pie chart for each indicator.

This activity was conducted on the parents of Harapan Bunda Kindergarten students. Of the 15 respondents involved, the number of respondents who filled out the questionnaire was 10 people. The distribution of respondent data is shown in Table 1.

Table 1. Respondent demographic data

\begin{tabular}{|l|c|c|c|}
\hline No. & \multicolumn{1}{|c|}{ Category } & Frequency (f) & Percentage (\%) \\
\hline \multirow{2}{*}{1.} & Gender & & \\
\cline { 2 - 4 } & a. Male & 5 & 50 \\
\hline & b. Female Total & 5 & 50 \\
\hline \multirow{2}{*}{2.} & Age & 10 & 100 \\
\cline { 2 - 4 } & $\begin{array}{l}\text { a. Parents of kindergarten students age 4-5 years } \\
\text { old }\end{array}$ & 4 & 40 \\
\cline { 2 - 4 } & $\begin{array}{l}\text { Parents of kindergarten students age 5-6 years } \\
\text { old }\end{array}$ & 6 & 60 \\
\hline \multicolumn{2}{|c|}{ Total } & 10 & 100 \\
\hline
\end{tabular}


Based on distribution of respondents who fill out the questionnaire as shown in Figure 4, the majority of respondents are parents of students with an age range of 5-6 years.

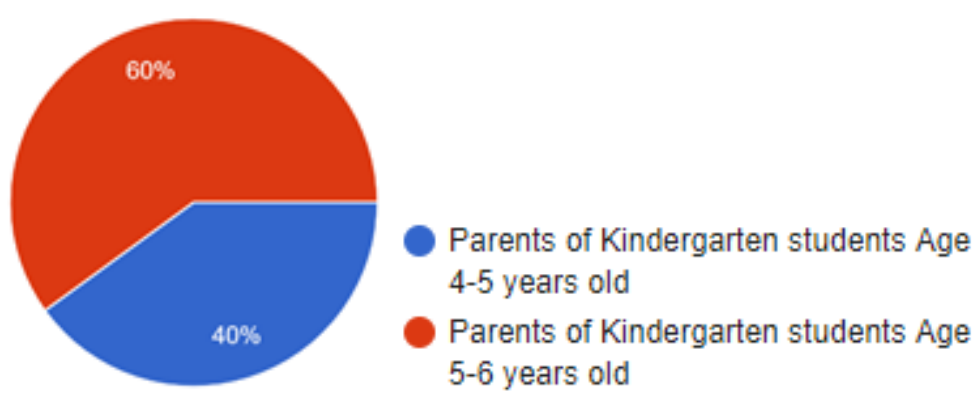

Figure 4. Distribution of Respondents Filling in the Questionnaire

\subsection{The results of the questionnaire on the effectiveness of sports learning through online} methods

Learning activities in Kindergarten are carried out online. The media used in learning is through zoom meetings and google forms. The activity conducted socialization of filling out google forms through a zoom meeting to parents of students.

\section{Student Response}

a) Psychological Complaints that Students Feel During Online Learning

Figure 5 shows psychological complaints experienced by respondents during online learning, among others: experiencing boredom as much as $70 \%$, or 7 students, and as many as $30 \%$ or 3 students not feeling any complaints.

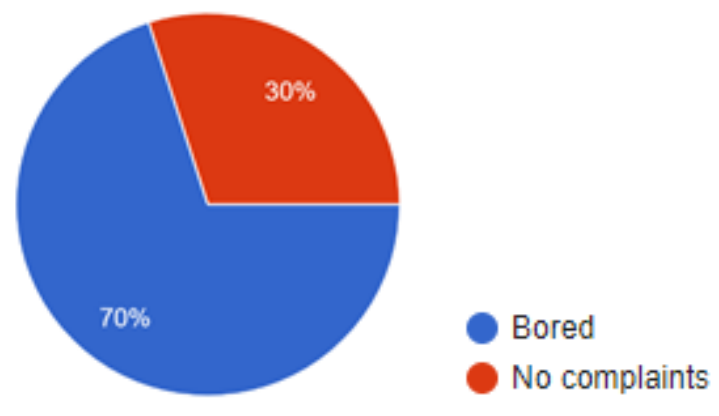

Figure 5. Psychic Complaints During Online Learning

b) Is the online sports learning material easy to understand and understand

As observed in Figure 6, it can be concluded that in receiving sports learning materials using the online method, the level of understanding of the respondents is different. As many as $50 \%$ or 5 students easily understand and as many as $50 \%$ or 5 students do not understand. 


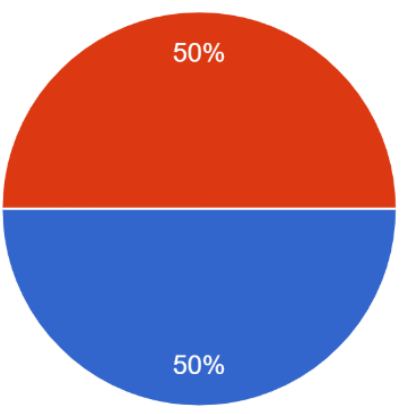

Easy understand

Do not understand

Figure 6. Ease of Understanding Materials during Online Learning

c) Physical benefits after doing sports learning online

The physical benefits felt by respondents during learning with online methods showed different results, this can be seen from Figure 7 which shows that students who feel physical benefits are $70 \%$ or 7 people and students who do not feel physical benefits are $30 \%$ or 3 people. Physical activity is very good for the body if it is carried out in a structured manner, especially during the Covid-19 pandemic because it can increase the body's immune system so it is not easy to get sick.

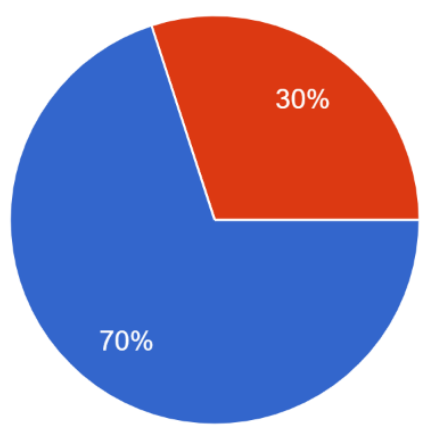

Figure 7. Physical Benefits of Online Learning

d) Do you think online learning during the Covid-19 pandemic is effective

According to Figure 8, the answers from respondents regarding online sports learning have various answers. Students who answered effective as much as $40 \%$ or 4 people then students who answered ineffectively as many as $60 \%$ or 6 people. 


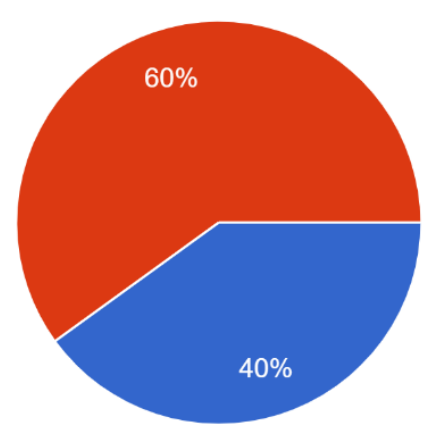

Figure 8. The Effectiveness of Online Sports Learning

\section{Facilities and infrastructure}

a) What type of internet connection do you use during online learning

By looking at Figure 9 that describe the implementation of online learning, many students use the type of internet connection quota as much as $70 \%$ or 7 students and who use WiFi as much as $30 \%$ or 3 people.

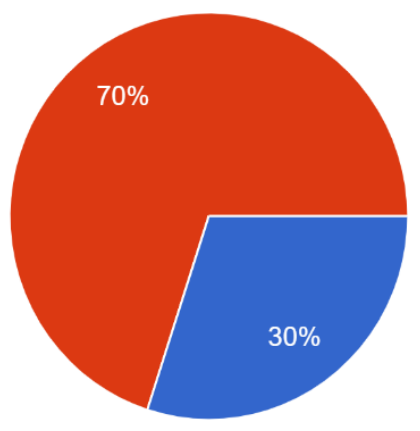

Figure 9. Type of Internet Connection Used

b) What obstacles do you face during online learning

In the implementation of learning through online methods, of course there are obstacles, Figure 10 shows as many as $60 \%$ or 6 students have limited quota constraints and as many as $40 \%$ or 4 students have unstable network constraints. 


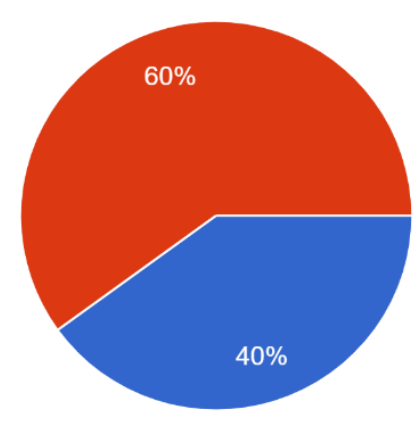

Unstable network

Limited quota

Figure 10. Obstacles Faced during Online Learning

c) Easy-to-Use App during online Learning

Applications that are easy to use when learning sports through online methods according to students include WhatsApp $90 \%$ or 9 students and as many as $10 \%$ or 1 student choosing Zoom Meeting.

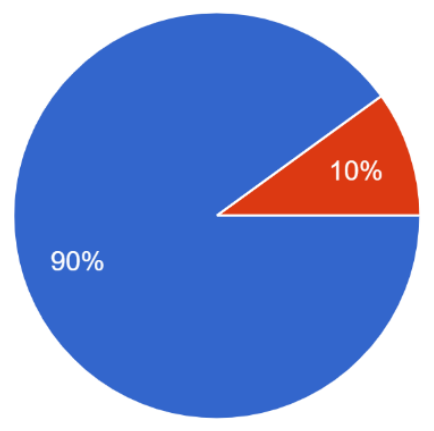

Figure 11. Applications that are Easy to Use during Online Learning

\section{Student Activities}

a) What is your attitude when the teacher is explaining the material

The implementation of online sports learning makes teachers are required to pay more attention and monitor their students' activities. According to Figure 12, 100\% or 10 students pay attention. 


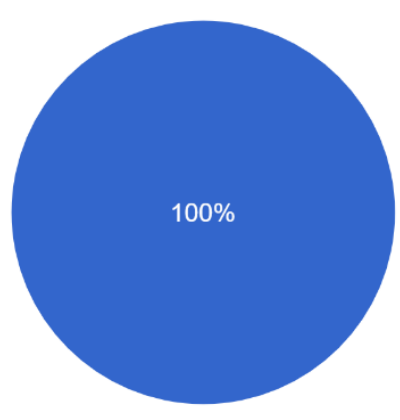

Notice

Not paying attention

Figure 12. Attitude when participating in Online Learning

b) How ready are you to take part in online sports lessons

To take part in the online learning process, there needs to be careful preparation so that learning is more effective, Figure 13 shows the readiness of students to take part in online sports learning, there are $80 \%$ or 8 students ready and as many as $20 \%$ or 2 people say they are not ready.

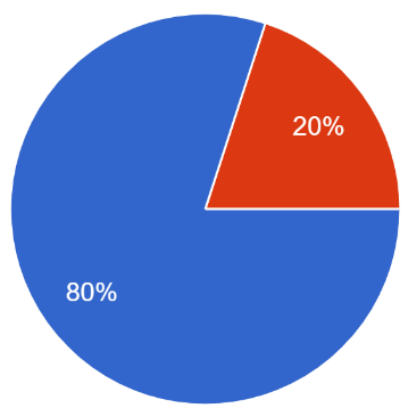

\section{Ready}

Not ready

Figure 13. Readiness to Participate in Online Sports Learning

c) Do you always follow sports lessons online

In the implementation of learning through online methods, interest is needed to always participate in every meeting. Figure 14 shows $90 \%$ or 9 students attending and $10 \%$ or 1 student not attending online learning. 


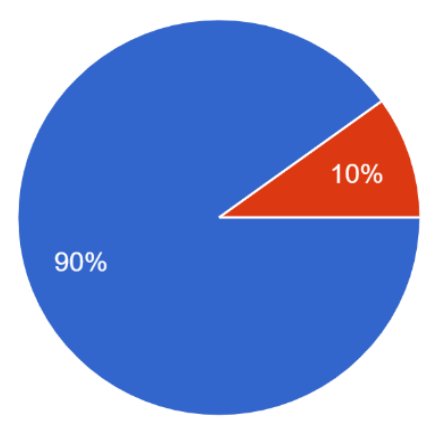

Present

Not present

Figure 14. Participation in Online Sports Learning

\section{Conclusion}

Online learning affects the achievement of early childhood development in Kindergarten. The results of this study indicate that the implementation of sports learning with the online method is quite effective, with students who are always present and the attitude of students who pay attention to the teacher when the learning process takes place. The results of this study can be used as a reference for further activity with it is recommended to involve more subjects and a wider area.

\section{Acknowledgement}

We acknowledged Bangdos, Universitas Pendidikan Indonesia. We thanks to Neneng Nurmayanti, S.Pd. from TK Harapan Bunda. This study is a part of community service Program : KKN Tematik Literasi 2021 (August-sept 2021) Kel 24 Lembaga Penelitian dan Pengabdian Masyarakat (LPPM), Universitas Pendidikan Indonesia. We also thank to Kantor Jurnal dan Publikasi, Directorate of International Affairs, Universitas Pendidikan Indonesia. We thank to Nissa Nur Azizah, Dwi Fitria Al Hussaeni, Dr.Eng. Asep Bayu Dani Nandiyanto, S.T.,M.Eng., Muktiarni, S.Pd.,M.Pd., Rina Maryanti,S.Pd., M.Pd.

\section{Reference}

Arikunto, S. 2001. Dasar-dasar Evaluasi Pendidikan (edisi revisi). Bumi Aksara.

Ayuni, D., Marini, T., Fauziddin, M. \& Pahrul, Y. 2020. Kesiapan Guru TK Menghadapi Pembelajaran Daring Masa Pandemi Covid-19. Jurnal Obsesi: Jurnal Pendidikan Anak Usia Dini, 5(1), 414-421.

Daheri, M., Juliana, Deriwanto \& Amda, A. D. 2020. Efektifitas WhatsApp sebagai Media Belajar Daring. Jurnal Basicedu, 3(2), 524-532. 
Firman, F. \&. Rahayu, S. 2020. Pembelajaran Online di Tengah Pandemi Covid-19. Indonesian Journal of Educational Science (IJES), 2(2) 81-89.

Handriani, O. I. \& Wulandari, S. S. 2020. Pembelajaran Daring sebagai Upaya Study Form Home (SFH) selama Pandemi Covid-19. Jurnal Pendidikan Administrasi Perkantoran (JPAP), 8(3), 496-503.

Hasanah, N.R., Adi, I.P.P. \& Suwiwa, I.G. 2021. Survey Pembelajaran PJOK Secara daring Pada Masa Pandemi Covid-19. Jurnal Kejaora : Jurnal Kesehatan Jasmani dan Olah Raga, 6(1), 189-196.

Efastri, S. M., \& Islami, C. C. 2021. Efektivitas Pembelajaran Online pada Masa Pandemi Covid-19 di Taman Kanak-Kanak. Jurnal Obsesi : Jurnal Pendidikan Anak Usia Dini, $6(2)$.

Lola, J. A., 2020. Strategi Pembelajaran di Taman Kanak-kanak (TK) pada Era Pandemi Covid-19. Jurnal Pendidikan Kristen, 1 (2).

Maesaroh, S., 2013. Peranan Metode Pembelajaran Terhadap Minat dan Prestasi Belajar Pendidikan Agama Islam. Jurnal Kependidikan, 1(1), 150-158.

Marheni, E., Ridwan, M., Afrizal, Purnomo, E. \& Soniawan, V. 2020. Meningkatkan Gairah Belajar PJOK Siswa Pasca Pandemi Covid-19. Suluah Bendang: Jurnal Ilmiah Pengabdian Kepada Masyarakat, 20(3), 149-158.

Trisnadewi, K. 2021. Tantangan Pembelajaran Daring Pada Pendidikan Anak Usia Dini. Jurnal Pendidikan Anak Usia Dini, 6(1), 29-37.

Wijoyo, H., 2020. Model Pembelajaran Menyongsong New Era Normal Pada Lembaga Paud Di Riau. Jurnal Sekolah, 4(3), 205-212. 